\title{
IMMUNITY IN DIABETES. II. RELATIVE IMPORTANCE OF NUTRITIONAL STATE AND OF BLOOD SUGAR LEVEL IN INFLUENCING DEVEL- OPMENT OF THE AGGLUTININ AFTER TYPHOID VACCINE
}

\author{
By RUSSELL RICHARDSON \\ (From the George S. Cox Medical Research Institute, University of Pennsylvania, Philadelphia)
}

(Received for publication February 2, 1935)

In a previous study it was shown that diabetic patients form antibodies in smaller amounts than non-diabetic controls (1). In the work demonstrating this, typhoid vaccine was used as the antigen and the agglutinin response was measured by Dreyer's macroscopic method. It was further shown that those patients who were in a poor clinical condition formed antibody in less amount than those whose condition was satisfactory.

The diabetic in poor condition presents a picture of hyperglycemia with undernourishment and loss of weight. With this there is an alteration in the amount and distribution of the body glycogen. It seemed, therefore, that a study of antibody formation in animals which, while not diabetic, were on the one hand undernourished, or on the other hand hyperglycemic, might aid in determining the significance of these factors in the decreased antibody formation of the diabetic.

\section{METHODS}

Normal adult rabbits, weighing about three kilograms, were used for these experiments. The antigen selected was standard $B$. typhosus vaccine. Two doses, of $0.1 \mathrm{cc}$. each were given intravenously one week apart, except in Experiment Number 2 , in which $0.4 \mathrm{cc}$. was given. The intravenous method of inoculation was used in order to avoid variations in absorption. Blood for agglutination tests was taken before each experiment and one week after the second dose of vaccine. Dreyer's macroscopic method was used for measuring the agglutinative titre of the serum in which agglutination occurred. In none of the rabbits did the blood show any agglutinative titre before the vaccine was given. Undernourishment was induced by feeding an insufficient diet, and hyperglycemia by the subcutaneous injection of epinephrine. Blood sugar determinations were done by the Benedict method.

In each of the under-feeding experiments the rabbits were weighed and divided into two groups. In the control group they were fed throughout the experiment the standard diet of the laboratory with the addition of carrots, beets, and oats amounting in all to double the basal caloric requirement. In the other group the rabbits were fed, throughout the experiment, the same variety of food reduced in amount, however, so that they received one half of the basal caloric requirement. After one week on these diets the animals were weighed and given the first dose of $B$. typhosus vaccine. One week later the same dose of vaccine was repeated. One week after this injection, blood was taken for measurement of the agglutinative titre. During this time the under-fed rabbits lost an average of 477 grams in weight. The control rabbits, on the other hand, maintained their previous weight, or in some cases increased slightly. Determinations of the concentration of glycogen in liver tissue were made as a further check on the state of nourishment. Liver tissue was removed under nembutal anesthesia from some animals in each group. The method used is a modification of the method of Cori, using cold $\mathrm{KOH}$, as described by Evans (2). The underfed rabbits had between 0.7 per cent and 2.0 per cent of glycogen in the liver, while the control animals had between 4.2 and 9.2 per cent. The results of these experiments are given in Table I. There was a marked difference in the appearance of the well and of the poorly fed rabbits after each dose of vaccine. The former showed no symptoms following the vaccine, even continuing to eat normally. The latter, however, were definitely ill, and in all except one experiment one or more of these rabbits died within twenty-four hours after an injection. In Experiments Number 2,5 and 6 there was a definitely smaller amount of antibody formed by the poorly nourished rabbits. In Experiment Number 4, while the difference is not so clearly evident, there was 
TABLE I

Effect of restricted diet compared with that of liberal diet on the agglutinative titre developed after intravenous typhoid vaccine

\begin{tabular}{|c|c|c|c|c|}
\hline \multirow{2}{*}{$\begin{array}{c}\text { Experi- } \\
\text { ment } \\
\text { num- } \\
\text { ber }\end{array}$} & \multicolumn{2}{|c|}{$\begin{array}{l}\text { Rabbits fed low caloric diet: } \\
\text { one-half basal requirement }\end{array}$} & \multicolumn{2}{|c|}{$\begin{array}{l}\text { Rabbits fed high caloric diet } \\
\text { twice the basal requirement }\end{array}$} \\
\hline & $\begin{array}{l}\text { Rabbit } \\
\text { number }\end{array}$ & $\begin{array}{l}\text { Agglutinative } \\
\text { titre }\end{array}$ & $\begin{array}{l}\text { Rabbit } \\
\text { number }\end{array}$ & $\begin{array}{l}\text { Agglutinative } \\
\text { titre }\end{array}$ \\
\hline 2 & $\begin{array}{l}232 \\
244 \\
245 \\
246 \\
247\end{array}$ & $\begin{array}{c}\text { died } \\
1 / 160 \\
\text { died } \\
1 / 2560 \\
\text { died }\end{array}$ & $\begin{array}{l}248 \\
249 \\
250\end{array}$ & $\begin{array}{l}1 / 10240 \\
1 / 5120 \\
1 / 5120\end{array}$ \\
\hline 4 & $\begin{array}{l}269 \\
267 \\
266 \\
262 \\
250 \mathrm{~B} \\
249 \mathrm{~A} \\
268\end{array}$ & $\begin{array}{l}1 / 320 \\
1 / 40 \\
1 / 640 \\
1 / 160 \\
1 / 1280 \\
1 / 2560 \\
1 / 320\end{array}$ & $\begin{array}{l}252 \\
251 \\
248 \text { A } \\
264 \\
253 \\
265 \\
256\end{array}$ & $\begin{array}{l}1 / 1280 \\
1 / 5120 \\
1 / 5120 \\
1 / 160 \\
1 / 5120 \\
1 / 320 \\
1 / 5120\end{array}$ \\
\hline 5 & $\begin{array}{l}186 \mathrm{~A} \\
191 \mathrm{~A} \\
187 \mathrm{~A} \\
183 \mathrm{~A}\end{array}$ & $\begin{array}{c}\text { died } \\
1 / 5120 \\
\text { died } \\
1 / 2560\end{array}$ & $\begin{array}{l}182 \mathrm{~A} \\
180 \mathrm{~A}\end{array}$ & $\begin{array}{l}1 / 10240 \\
1 / 10240\end{array}$ \\
\hline \multirow[t]{2}{*}{6} & $\begin{array}{l}188 B \\
273 B \\
272 B\end{array}$ & $\begin{array}{c}1 / 1280 \\
1 / 2560 \\
\text { died }\end{array}$ & $\begin{array}{l}248 B \\
275 B\end{array}$ & $\begin{array}{l}1 / 20480 \\
1 / 10240\end{array}$ \\
\hline & & $\begin{array}{l}\text { Glycogen content } \\
\text { of liver }\end{array}$ & & $\begin{array}{l}\text { Glycogen content } \\
\text { of liver }\end{array}$ \\
\hline 2 & $\begin{array}{l}232 \\
244 \\
245 \\
246 \\
247\end{array}$ & $\begin{array}{c}\text { per cent } \\
0.7 \\
1.7 \\
0.9 \\
2.0 \\
1.1\end{array}$ & $\begin{array}{l}248 \\
249 \\
250\end{array}$ & $\begin{array}{c}\text { per cent } \\
9.1 \\
8.4 \\
4.2\end{array}$ \\
\hline 6 & $\begin{array}{l}188 \mathrm{~B} \\
273 \mathrm{~B}\end{array}$ & $\begin{array}{l}0.7 \\
1.6\end{array}$ & $\begin{array}{l}248 B \\
256\end{array}$ & $\begin{array}{l}9.2 \\
8.8\end{array}$ \\
\hline
\end{tabular}

a probably significant difference between the results in the two groups. The average of the logarithm of the titre for the undernourished rabbits in Experiment Number 4 is $2.6 \pm 0.22$ and that for the well nourished is $3.2 \pm 0.19$ giving a difference of $0.6 \pm 0.29$.

In Table II are shown the results of a slightly different experiment. Here one group of rabbits received six intravenous injections of $8 \mathrm{cc}$. of 25 per cent solution of glucose at hourly intervals immediately before the vaccine was given. The control group received normal salt solution in place of the glucose solution. One cc. of vaccine was given intravenously, and the same procedure, administration of glucose followed by vaccine, was repeated one week later. Blood for ag-
TABLE II

Effect of regular diet compared with that of liberal diet reinforced with glucose on the agglutinative titre developed after intravenous typhoid vaccine.

Experiment Number 1

\begin{tabular}{|c|c|c|c|}
\hline \multicolumn{2}{|c|}{$\begin{array}{l}\text { Rabbits without glucose } \\
\text { and with regular diet }\end{array}$} & \multicolumn{2}{|c|}{$\begin{array}{l}\text { Rabbits with glucose and } \\
\text { high caloric diet }\end{array}$} \\
\hline $\begin{array}{l}\text { Rabbit } \\
\text { number }\end{array}$ & $\underset{\text { titre }}{\text { Agglutinative }}$ & $\underset{\text { number }}{\text { Rabbit }}$ & $\underset{\text { titre }}{\text { Agglutinative }}$ \\
\hline $\begin{array}{l}183 \\
184 \\
185 \\
188 \\
189\end{array}$ & $\begin{array}{c}1 / 20480 \\
\text { died } \\
\text { died } \\
1 / 20480 \\
1 / 20480\end{array}$ & $\begin{array}{l}180 \\
181 \\
182 \\
186 \\
187\end{array}$ & $\begin{array}{c}1 / 40960 \\
\text { died } \\
1 / 81920 \\
1 / 40960 \\
1 / 81920\end{array}$ \\
\hline
\end{tabular}

glutination test was taken one week after the second dose. During the experiment the rabbits which received normal salt solution were given the regular laboratory diet, while those which had glucose received such food as carrots and oats in larger quantity. One rabbit in the latter group died following the vaccine while two in the control group died. In this experiment also the animals with the greater caloric intake consistently formed more agglutinin than did the others.

It appears from these experiments that animals which are well fed are better able to form antibody than those which have a lower caloric intake.

In the experiments on hyperglycemia the rabbits were fed a full diet, the same as that given to the control rabbits in the first group of experiments described. In each experiment they were divided into two groups, one receiving epinephrine injections, the other acting as controls. Both groups were given $B$. typhosus vaccine, and blood was taken for agglutination as in the former experiments. Two injections of $1.0 \mathrm{cc}$. each of $1-1000$ solution of epinephrine were given to the epinephrine group subcutaneously daily at 9 a.m. and 4 p.m. for seven days before the first dose of vaccine and continuously throughout the experiment. Two rabbits out of thirteen which received epinephrine died before any vaccine was given them. The vaccine was given one hour after the 9 o'clock epinephrine injection so that the blood sugar was between 240 and $410 \mathrm{mgm}$. per $100 \mathrm{ml}$. of blood at the time. Blood for sugar determination was taken at intervals up to five hours after the injections of epinephrine and was found to contain from 150 to $253 \mathrm{mgm}$. of 
sugar per $100 \mathrm{ml}$. of blood. There was considerable variation in the effect of the epinephrine on the blood sugar of different animals, but on the whole it appeared that hyperglycemia was present for from seven to fourteen hours in each day.

The results of these experiments are shown in Table III. There was no significant difference

TABLE III

Effect of hyperglycemia induced by repeated subcutaneous injections of epinephrine on the agglutinative titre developed after intravenous typhoid vaccine

\begin{tabular}{|c|c|c|c|c|}
\hline \multirow{2}{*}{$\begin{array}{c}\text { Experi- } \\
\text { ment } \\
\text { num- } \\
\text { ber }\end{array}$} & \multicolumn{2}{|c|}{$\begin{array}{c}\text { Rabbits with } \\
\text { hyperglycemia }\end{array}$} & \multicolumn{2}{|c|}{$\begin{array}{l}\text { Rabbits with normal } \\
\text { blood sugar }\end{array}$} \\
\hline & $\begin{array}{l}\text { Rabbit } \\
\text { number }\end{array}$ & $\underset{\text { titre }}{\text { Agglutinative }}$ & $\begin{array}{l}\text { Rabbit } \\
\text { number }\end{array}$ & $\underset{\text { titre }}{\text { Agglutinative }}$ \\
\hline 3 & $\begin{array}{l}252 \mathrm{C} \\
253 \mathrm{C}\end{array}$ & $\begin{array}{l}1 / 20480 \\
1 / 40960\end{array}$ & $\begin{array}{l}251 \mathrm{C} \\
256 \mathrm{C}\end{array}$ & $\begin{array}{l}1 / 20480 \\
1 / 40960\end{array}$ \\
\hline 6 & $250 \mathrm{~B}$ & $1 / 10240$ & $\begin{array}{l}248 B \\
275 B\end{array}$ & $\begin{array}{l}1 / 20480 \\
1 / 10240\end{array}$ \\
\hline 7 & $\begin{array}{r}294 \\
20 \\
23\end{array}$ & $\begin{array}{l}1 / 20480 \\
1 / 5120 \\
1 / 5120\end{array}$ & $\begin{array}{r}291 \\
22\end{array}$ & $\begin{array}{l}1 / 20480 \\
1 / 40960\end{array}$ \\
\hline 8 & $\begin{array}{r}25 \\
27 \\
28 \\
296 \\
298\end{array}$ & \begin{tabular}{l}
\multicolumn{1}{c}{ died } \\
$1 / 10240$ \\
$1 / 5120$ \\
$1 / 10240$ \\
$1 / 320$
\end{tabular} & $\begin{array}{l}26 \\
31\end{array}$ & $\begin{array}{l}1 / 2560 \\
1 / 10240\end{array}$ \\
\hline
\end{tabular}

between the agglutinative titres of the two groups. It would seem from these experiments, therefore, that hyperglycemia maintained by repeated injection of epinephrine has little or no effect on the amount of antibodies appearing in the blood.

In a previous investigation we determined the ability of the diabetic to form antibodies as compared with that of the non-diabetic, by making agglutination tests on 41 diabetics and 39 nondiabetics following typhoid vaccine given according to the usual method (1). A reexamination of our records of these experiments shows that from 2 to 4 blood sugar determinations were made on each patient during the period of the inoculations. Eighteen patients developed an agglutinative titre of $1 / 5,120$ to $1 / 20,480 ; 18$ other patients agglutinated the antigen in dilutions of only $1 / 80$ to $1 / 1280$. In the high titre group the blood sugar determinations varied from 100 to $360 \mathrm{mgm}$. per $100 \mathrm{ml}$. with an average of $204 \pm 22 \mathrm{mgm}$. In the low titre group the blood sugar varied between 135 and $348 \mathrm{mgm}$. per $\mathrm{ml}$. with an average of $225 \pm 19 \mathrm{mgm}$. It is evident that those patients who developed a low and those who developed a high agglutinative titre did not essentially differ in their blood sugar concentration.

In the same study (1) the bactericidal power was measured by adding the blood of diabetics and of non-diabetics to dilutions of from $1 / 10$ to $1 / 1,000,000$ of broth cultures of $B$. coli, Pneumococcus, Staphylococcus aureus, Streptococcus hemolyticus and Streptococcus viridans. The killing power of the bloods of patients and controls was compared (see (1) Table II). The results from patients with blood sugar under $200 \mathrm{mgm}$. and over $200 \mathrm{mgm}$. per $100 \mathrm{ml}$. of blood were grouped separately. It was evident that there was no significant difference in the bactericidal power of the two groups. These findings are consistent with those reported in this study.

\section{DISCUSSION}

Antibody formation may probably be taken as a measure of a part of the defense of the body against infection, and a deficient antibody formation as evidence of disordered cellular metabolism. Two features are common to diabetic patients and to the under-fed rabbits of these experiments; namely, a low caloric intake and a lowered glycogen concentration in certain tissues. We cannot assert that the impairment in cellular metabolism which leads to the deficient antibody formation is the same in these under-fed rabbits and in the diabetic. However, inasmuch as hyperglycemia per se had no significant influence on the antibody formation, whereas the state of nutrition apparently did, it is suggested that the susceptibility to infection on the part of the diabetic is due to a disordered cellular nutrition closely associated with the diminution of cellular glycogen reserve.

\section{CONCLUSIONS}

Under-fed rabbits with depleted liver glycogen developed definitely lower agglutinative titre after typhoid vaccine than did well-fed controls with higher liver glycogen. Hyperglycemia maintained by repeated doses of epinephrine had no significant influence on the agglutinative titre developed in rabbits after typhoid vaccine. These 
results are discussed in relation to observations on diabetic patients that no correlation was observed in diabetics between fasting blood sugar concentration and either the agglutinative titre developed after typhoid vaccine or the bactericidal power of the diabetic blood.

It is suggested that the state of cellular nutrition is more important than the level of blood sugar in determining the antibody response.

The author wishes to acknowledge with thanks the suggestions of Dr. Herbert Fox and the cooperation of the William Pepper Laboratory of Clinical Medicine.

\section{BIBLIOGRAPHY}

1. Richardson, Russell, Immunity in diabetes: influence of diabetes on the development of antibacterial properties in the blood. J. Clin. Invest., 1933, 12, 1143.

2. Evans, Gerald, The glycogen content of the rat heart. J. Physiol., 1934, 82, 468. 